\title{
Sciendo
}

\section{STEM CELL THERAPY FOR PERIANAL CROHN'S DISEASE}

\author{
Oleg Knyazev", Anna Kagramanova ${ }^{1, \#}$, Albina Lischinskaya1, Irina Korneeva ${ }^{1}$, \\ Mariya Zvyaglova', Anait Babayan ${ }^{1}$, Anatoliy Konoplyannikov², and Asfold Parfenov ${ }^{1}$ \\ 1 The A. S. Loginov Moscow Clinical Scientific Centre, 86 Schosse Entuziastov, 111123, Moscow, RUSSIA \\ ${ }^{2}$ Clinical Radiological Research Centre, 4 Koroleva Str., Obninsk, RUSSIA \\ \# Corresponding author, kagramanova@me.com
}

Communicated by Aivars Lejnieks

\begin{abstract}
The goal of the study was to compare the effect of combination therapy (local and systemic administration) with bone marrow mesenchymal stromal cells (MSC), anticytokine therapy with infliximab (IFX), and antibiotic (AB)/immunosuppressive (IS) therapy on the frequency of healing of simple perianal fistulas in Crohn's disease. Three patient groups were used in our study. The $1^{\text {st }}$ group of patients (age 19 to 58 years, mean 29 years, $n=12$ ) received MSCs culture systemically and locally. The $2^{\text {nd }}$ group of patients with $C D$ (age 20 to 68 years, mean age 36 years, $n=$ 10) received anticytokine therapy with infliximab (IFX). The $3^{\text {rd }}$ group of patients with $C D$ (age 20 to 62 years, mean age 28 years, $n=14$ ) received antibiotics $(A B)$ and immunosuppressors (IS). Treatment effect was assessed by the index of perianal activity of Crohn's disease (PCDAI) and the frequency of relapses. After 12 weeks, in the $1^{\text {st }}$ group, healing of simple fistulas was noted in $8 / 12$ patients $(66.6 \%)$, in the $2^{\text {nd }}$ group in $6 / 10(60.0 \%)$ and in the $3^{\text {rd }}$ group in $1 / 14$ patients (7.1\%). After six months, in the $1^{\text {st }}$ group of patients healing of simple fistulas occurred in $8 / 12$ $(66.6 \%)$, in the $2^{\text {nd }}$ group in $6 / 10(60.0 \%)$ and in the $3^{\text {rd }}$ group in $1 / 14$ patients $(7.1 \%)$. After 12 months, in the $1^{\text {st }}$ group, healing of simple fistulas was observed in $7 / 12(58.3 \%)$, in the $2^{\text {nd }}$ group in $6 / 10(60.0 \%)$ and in the $3^{\text {rd }}$ group in 2/14 patients (14.3\%). After 24 months, among the patients of the $1^{\text {st }}$ group, fistula closure was observed in $5 / 12$ patients $(41.6 \%)$, in the $2^{\text {nd }}$ group in $4 / 10(40.0 \%)$ and in the $3^{\text {rd }}$ group in 0/14 patients (0.0\%). Combined cellular and anticytokine therapy of $C D$ with perianal lesions significantly contributes to more frequent and prolonged closure of simple fistulas, as compared to antibiotics/immunosuppressors, and to a decrease in the frequency of recurrence of the disease.
\end{abstract}

Key words: inflammatory bowel diseases, infliximab, fistula form, mesenchymal stromal cells, cell treatment.

\section{INTRODUCTION}

Crohn's disease $(\mathrm{CD})$ is a chronic inflammatory progressive disease of the gastrointestinal tract that primarily affects the terminal ileum. Depending on the clinical course, there are three phenotypes (forms) of CD: inflammatory, stenosing, and penetrating (Sachar et al., 1992). Usually, in the very beginning of $\mathrm{CD}$ it is characterised by granulomatous inflammation of the intestinal mucosa, although, over time, many patients will develop strictures or fistulas as a result of uncontrolled progression of the inflammatory process. Over 20 years, $88 \%$ of patients develop strictures (18\%) and fistulas (70\%) (Cosnes et al., 2002).

The clinical course of $\mathrm{CD}$ and the rate of progression vary significantly. In $43 \%$ of patients, the disease begins as a se- vere attack, followed by relatively occasional symptoms over the next ten years (Solberg et al., 2008). However, in $51 \%$ of patients, CD has a chronic course (19\%) or has a relapsing pattern (32\%) (Munkholm et al., 1995; Solberg et al., 2008).

The eventual goal of treating CD is the healing of affected bowel segments, increasing the duration of remission, reducing the frequency and severity of complications, and improving the quality of life of patients (Rutgeerts et al., 2004; Solberg et al., 2008; Schnitzler et al., 2009). Treatment of patients with $\mathrm{CD}$ should be done with consideration of the prognostic factors of disease progression. According to the consensus of the European Crohn's and Colitis Organisation (ECCO), the clinical course of $\mathrm{CD}$ can be predicted based 
on clinical symptoms at the time of the diagnosis, patient age, medical history, extraintestinal manifestations, as well as the presence of stenosis and fistula. Perianal fistulas are the most common types of fistulas in CD that might be encountered (Dignass et al., 2010). The total prevalence of perianal fistulas in the structure of $\mathrm{CD}$ varies from 21 to $23 \%$, while in the first year of the course of the disease the prevalence is $12 \%$, in five years - $15 \%$, in ten years $21 \%$, in 20 years - 26\% (Hellers et al., 1980; Schwartz et al., 2002; Tang et al., 2006). Especially prevalent for CD are fistulas of the rectum. Rectal fistulas are not a lifethreatening complication, but they definitely worsen quality of life and are difficult to be treated. Therefore, at present, perianal lesions are considered as disabling manifestations of CD. They are presented in 25-80\% of patients and may precede abdominal symptoms for a few years (Lichtenstein et al., 2005).

Perianal fistulas can be divided into simple and complex. Simple perianal fistulas include superficial nonrectovaginal, low intra- and transsphincteric fistulas with a single external opening, without clinical signs of abscess formation and acute inflammatory process without stricture of the anal canal. Complex fistulas include any form (with respect to the anal sphincter) of high position fistulas with multiple external openings, with signs of abscess formation, rectovaginal fistulas, as well as fistulas with stricture of the anal canal. In cases when endoscopy confirms severe specific proctitis of $\mathrm{CD}$, then the fistula are categorised as complex (Sandborn et al., 2003).

The fistulous form of $\mathrm{CD}$ is an indication for prescribing biological therapy (BT) with genetically engineered biological drugs at the time of diagnosis ("Top-down" therapy).

A clinical study evaluating the effectiveness of infliximab (IFX) for the treatment of patients with a fistulous form of CD (ACCENT II) confirmed its positive effect. However, a high risk of developing recurrence of CD remains. Therefore, the search for new approaches and methods of treatment of this form of CD remains relevant (Williamson et al., 1995).

Mesenchymal stromal cells (MSC) have immunomodulatory properties, high regenerative potential and have been used by authors in the complex treatment of IBD since 2008 (Knyazev et al., 2013). Currently, they are also used to treat fistulous CD and perianal fistulas (Aguilera-Castro et al., 2017). Italian scientists carried out a study on the safety and effectiveness of the local administration of autologous bone marrow MSCs in the treatment of fistulous form of CD. Based on the acquired results, it was concluded that their local administration is a safe and effective method of therapy for this form of CD (García-Olmo et al., 2005; 2009; Ciccocioppo et al., 2011).

A number of researchers have shown that there are differences in efficacy between systemic and local administration of MSCs for the treatment of the fistulous form of CD. In an experimental model of colitis, Gonzalez-Rey et al.
(2009) found that MSCs obtained from adipose tissue, when administered intraperitoneally, migrate by the "homing" principle in the exact area of inflammation of the colon. Duijvestein et al. (2011) observed a similar "homing" effect using human bone marrow MSCs with systemic administration. However, only a small number of labelled MSCs were found in the inflamed intestine with systemic administration of cell culture (Duijvestein et al., 2011). It is believed that the I/V route of administration of MSCs has a systemic immunomodulating effect, contributing to the restoration of damaged tissue. With local administration, a greater number of MSCs reach damaged tissues than with I/V administration, which provides more intensive tissue regeneration due to the creation of a high concentration of soluble growth factors in the zone of damage.

The incidence of serious adverse events caused by transplantation of MSCs is less than $1.75 \%$. The most common possible adverse effects are pain at the injection site, fever and the formation of perianal abscesses (Lei Yea et al., 2016; Panes, 2016).

The aim of our study was to compare the effect of combination (local and systemic administration) therapy of bone marrow MSCs, anticytokine (IFX) therapy and antibiotic (AB)/immunosuppressive (IS) therapy on healing of simple perianal fistula in $\mathrm{CD}$.

\section{METHODS}

The study included 36 patients aged 18 to 70 years with an average $\mathrm{CD}$ activity index (CDAI) and average activity index of the perianal form of CD (PCDA). Patients were informed of the purpose of the study, the possible risks and signed an informed consent form for this treatment method.

"The protocol of limited clinical trials of the method of systemic transplantation of allogeneic MSCs in human bone marrow in patients with ulcerative colitis and CD" was approved by the Scientific Council and the local ethics committee of the A. S. Loginov MCSC. This study was conducted before the entry into force of the Federal Law of 23 June 2016 No. 180-FL "On Biomedical Cellular Products".

Patients with $\mathrm{CD}$ had the following perianal lesions: six $(16.6 \%)$ patients had ulcers-fissures of the anal canal, 23 $(63.9 \%)$ had simple fistulas of the rectum, and seven $(19.5 \%)$ had a combination of two types of perianal lesions.

The patients were divided into three groups depending on the therapy method. The first group of patients aged 19 to 58 years (mean age 29 years, $n=12$ ) received the MSCs culture systemically (according to the scheme) and locally, as shown in Figure 1. The second group of patients with CD (age 20 to 68 years, mean age 36 years, $n=10$ ) received IFX anti-cytokine as a standard regimen at a dose of 5 $\mathrm{mg} / \mathrm{kg}$ body weight. The third group of patients with $\mathrm{CD}$ (age 20 to 62 years, mean age 28 years) $(n=14)$ received antibiotics (metronidazole and ciprofloxacin) and immunosuppressants. 


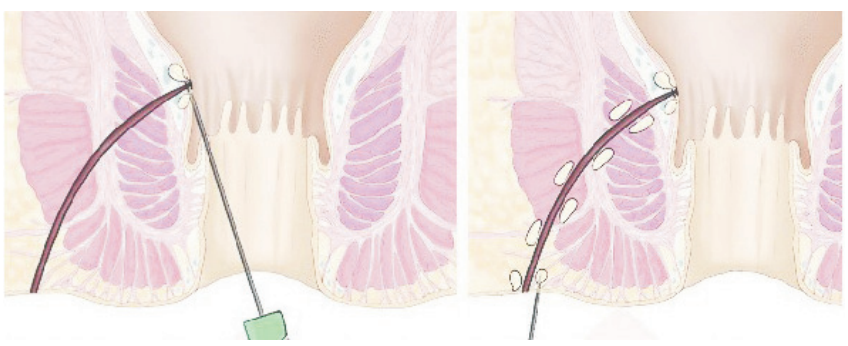

Fig. 1. Scheme of introducing mesenchymal stromal cells into the area around the canal of the fistula (De la Portilla et al., 2006).

Table 1. Initial demographic and clinically related laboratory indicators of Crohn's disease activity in groups of patients

\begin{tabular}{lcc|c}
\hline \multicolumn{1}{c|}{ Parameters } & $\begin{array}{c}1 \text { group } \\
(\mathrm{n}=12)\end{array}$ & $\begin{array}{c}2 \text { group } \\
(\mathrm{n}=10)\end{array}$ & $\begin{array}{c}3 \text { group } \\
(\mathrm{n}=14)\end{array}$ \\
\hline Age (mean, years) & 29 & 36 & 28 \\
Males (n/\%) & $5 / 41.6$ & $4 / 40.0$ & $8 / 57.1$ \\
Females (n/\%) & $7 / 58.4$ & $6 / 60.0$ & $6 / 42.9$ \\
Disease duration $(\mathrm{M} \pm \mathrm{m}$, & $7.2 \pm 0.9$ & $6.7 \pm 0.9$ & $6.8 \pm 0.7$
\end{tabular}

years)

Previous therapy of CD within last 6 months.

$\begin{array}{lccc}\text { Antibiotics }(\mathrm{n} / \%) & 11 / 91.7 & 7 / 70.0 & 12 / 85.7 \\ \text { Corticosteroids }(\mathrm{n} / \%) & 9 / 75.0 & 8 / 80.0 & 6 / 42.9 \\ \text { No treatment }(\mathrm{n} / \%) & 1 / 8.3 & 2 / 20.0 & 2 / 14.3 \\ \text { CDAI, points } & 328.6 \pm 12.2 & 326.5 \pm 13.8 & 323.6 \pm 8.9 \\ \text { PCDAI, points } & 4.7 \pm 0.3 & 4.7 \pm 0.3 & 4.8 \pm 0.3 \\ \text { Platelets, } 10^{9} / 1 & 387.2 \pm 34.9 & 386.6 \pm 44.4 & 389.7 \pm 44.4 \\ \text { CRP, mg/l } & 23.5 \pm 5.3 & 25.0 \pm 6.1 & 21.6 \pm 4.6 \\ \text { ESR, mm/h } & 36.9 \pm 5.6 & 36.3 \pm 5.6 & 30.2 \pm 2.9 \\ \text { Haemoglobin, g/l } & 107.6 \pm 14.1 & 101.5 \pm 9.7 & 110.7 \pm 11.4\end{array}$

Types of perianal lesions

\begin{tabular}{lccc}
$\begin{array}{l}\text { Fissure and ulcers } \\
\text { of the anal canal }\end{array}$ & $2 / 16.6$ & $3 / 30.0$ & $1 / 7.2$ \\
$\begin{array}{l}\text { Simple fistulas } \\
\text { of the rectum }\end{array}$ & $8 / 66.2$ & $4 / 40.0$ & $10 / 71.4$ \\
$\begin{array}{l}\text { Rectovaginal fistula } \\
\text { The combination of two }\end{array}$ & - & $1 / 10.0$ & - \\
\hline
\end{tabular}

types of perianal fistula

CDAI, Crohn's disease activity index PCDAI, perianal activity of Crohn's disease

The main initial demographic and clinically related laboratory indicators of CD activity are presented in Table 1.

Ano- and sigmoidoscopy was performed for all patients with rectal fistulas. To obtain a more precise view of the complexity of the canal course, and of the presence of pouches and purulent intrusions, fistulography was performed with the introduction of a radiopaque substance directly into the fistulous tract and subsequent radiography. If necessary, patients underwent transrectal ultrasound (TRUS) or magnetic resonance imaging (MRI).

Type of the rectal fistula was determined based on the $\mathrm{X}$-rays by the approximate height of the inner hole in accordance with the recommendations developed by the A. Ryzhikh State Research Centre of Coloproctology (Khalif, 2013, at p. 9.).
Bone marrow harvesting, MSCs cultivation from bone marrow cells of a patient or donor, and freezing and storage of MSCs in liquid nitrogen were performed in accordance with a previously published procedure [(Tsyb et al., 2004). Before the introduction of MSCs, inoculation was made from cell populations obtained from cell cultures to control possible bacterial contamination (which was not observed in any case).

\section{Systemic and local administration of allogeneic bone} marrow MSCs. Systemic transplantation of MSCs was performed by a single intravenous drip injection into the cubital vein under the control of blood pressure, pulse and temperature for 40-60 minutes. In order to complete systemic transplantation of 150-200 million allogeneic MSCs grown in culture, the cells were weighed in $200 \mathrm{ml}$ of normal saline containing heparin at a concentration of $50 \mathrm{u} / \mathrm{ml}$, and then they were injected into the patient for 40-60 minutes by a drip chamber. Before the introduction of MSCs, in order to prevent post-transfusion complications, the patient was injected with 60-90 mg of intravenous prednisolone or $2 \mathrm{ml}$ of chloropyramine. Re-introduction of MSCs was performed after 1 to 2 weeks, then after 3 and 12 months after the first injection to consolidate the previously obtained effect.

Local treatment was carried out along the fistulous tract: 40 million MSCs were injected through four injection points of $1 \mathrm{ml}$ of normal saline containing 10 million MSCs. Then, after 4 and 8 weeks, 40 million MSCs were re-introduced into the fistula area (Fig. 2).

Evaluation of the effect of therapy was based on the dynamics of CDAI and PCDAI (Table 2) and the relapse rate during the observation period.

Control ano- and rectosigmoscopy, TRUS or MRI were performed after $3,6,12$, and 24 months from the start of therapy. The healing dynamics of the external opening of the fistula, the amount of discharge, pain, sexual activity and the degree of induration around the fistulous tract were evaluated.

Statistical data processing was performed using the software package Microsoft ${ }^{\circledR}$ Office Excel 2003; Statistica v. 6.0; Primer of Biostatistics Version 4.03 by Stanton A. Glantz 1998. The Student's t-test was used to determine significant differences between means in the sets of data. When determining the risks of CD relapse according to the "incidence" method, new cases of outcomes (relapses) arising during the observation in the patient groups were taken into account. The analysis of four-fold contingency tables using the nonparametric $\chi 2$ with Yates correction statistical criteria was performed.

\section{RESULTS}

In all groups of patients, prior to treatment, there was minimal or moderate discharge of mucus from the anus, discomfort in the perianal region, presence of two or three perianal 


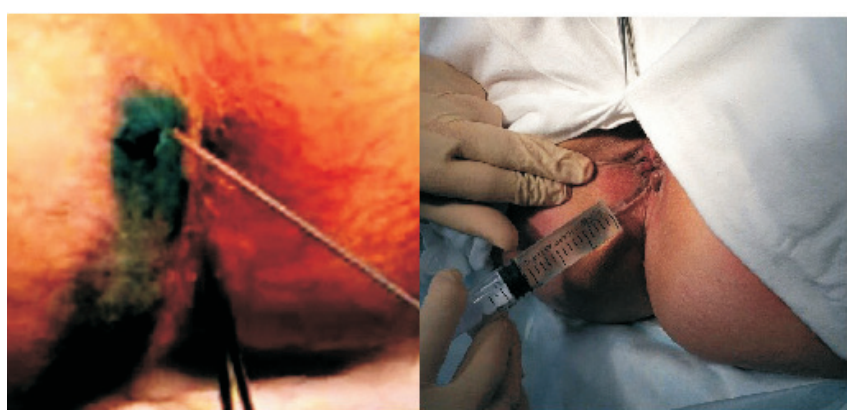

Fig. 2. Introduction of mesenchymal stromal cells in the area of fistulous tract.

Table 2. The activity index of perianal Crohn's disease

\begin{tabular}{c|c|l}
\hline Feature & Points & \multicolumn{1}{c}{ Characteristic } \\
\hline Discharge & 0 & No discharge \\
& 1 & Minimal mucous discharge \\
& 2 & Moderate mucous or purulent discharge \\
& 3 & Significant discharge \\
& 4 & Macroscopically noticeable presence \\
& & of faeces \\
\hline
\end{tabular}

Pain and restriction of $\quad 0 \quad$ No restriction of physical activity

physical activity 1 Slight discomfort, no restriction of physical activity

2 Moderate discomfort, some restriction of physical activity

3 Significant discomfort, significant limitation of physical activity

4 Severe pain, inability to exercise

\begin{tabular}{lll}
\hline Restriction of sexual & 0 & No restriction of sexual activity \\
activity & 1 & Slight restriction of sexual activity \\
& 2 & Moderate restriction of sexual activity \\
& 3 & Significant restriction of sexual activity \\
& 4 & Inability to have sex \\
\hline
\end{tabular}

Type of perianal $\quad 0 \quad$ Absence of perianal lesions and skin lesions overgrowth

1 Anal fissure or rupture of the mucosa

$2<3$ perianal fistulas

$3>3$ perianal fistulas

$4 \quad$ Fistulous ulceration of the anal sphincter with significant skin undermining

$\begin{array}{lll}\text { Degree of induration } & 0 & \text { Absence of induration } \\ & 1 & \text { Minimal induration } \\ & 2 & \text { Moderate induration } \\ & 3 & \text { Significant induration } \\ 4 & \text { Obvious fluctuation or abscess }\end{array}$

fistulas revealed during clinical examination, TRUS or MRI, and anal ulcers or fissures with induration (or absence) upon palpation of the surrounding tissue. The presence of fistulas often did not affect the sexual activity of patients. Thus, the initial PCDAI in the groups was $4.7 \pm 0.3$; $4.7 \pm 0.3$ and $4.8 \pm 0.3$ points, respectively $(p>0.05)$. There were no side effects during the follow-up period.

After 12 weeks of observation, in $8(66.6 \%)$ of 12 patients of the $1^{\text {st }}$ group and in $6(60.0 \%)$ of patients of the $2^{\text {nd }}$ group with ulcers/fissures of the anal canal and fistulas of
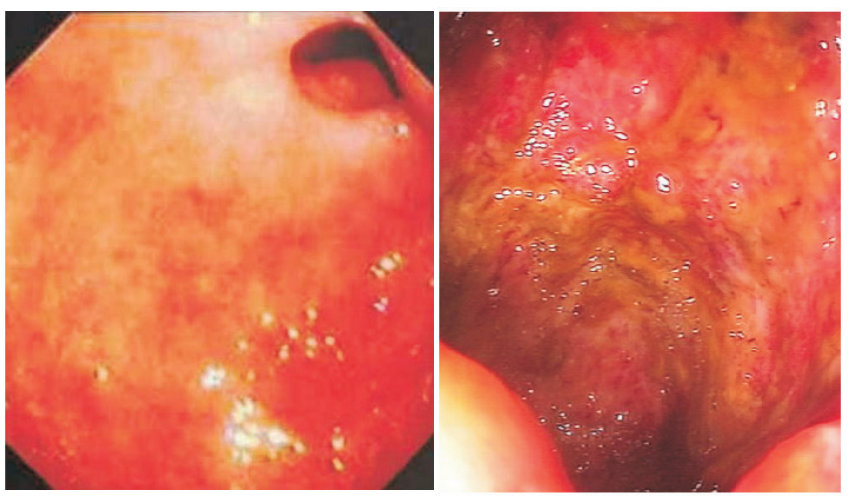

Fig. 3. Colonoscopy. Patient P., 38 years old. The internal opening of the fistulous tract in the lower part of the rectum ampulla before the introduction of mesenchymal stromal

Fig. 4. Colonoscopy. Patient P., 38 years old. Healed fistula after administration of mesenchymal stromal cells after 12 weeks. cells.

the rectum, epithelization has occurred, the amount of discharge was reduced, the feeling of discomfort disappeared and there was complete closure of the fistulous tract (Figs. 3 and 4). In two patients from the $1^{\text {st }}$ and $2^{\text {nd }}$ groups (16.7\% and $20.0 \%$ ), partial closure of the fistulous tracts was noted, which was regarded by us as a response to MSCs or anticytokine therapy (RR $1.11 ; 95 \%$ CI $0.58-2.12, p=0.9$ ). In patients of the $3^{\text {rd }}$ group receiving antibacterial and immunosuppressive therapy, fistulas were closed in one patient (7.1\%). Partial response with a decrease in serous discharge, pain, etc. was observed in four patients $(28.6 \%)$. In nine patients $(64.3 \%)$, there was no response to the therapy.

Figure 5 shows changes in PCDAI during treatment. In all groups of patients there was a significant decrease in the average values of PCDAI: in the $1^{\text {st }}$ group from $4.7 \pm 0.3$ to $1.8 \pm 0.38$ points $(p<0.05)$, in the $2^{\text {nd }}$ group from $4.7 \pm 0.3$ to $1.9 \pm 0.45$ points $(p<0.05)$, and in the $3^{\text {rd }}$ group from $4.8 \pm 0.25$ to $2.57 \pm 0.46$ points $(p<0.05)$.

After 26 weeks, in one patient (10.0\%) receiving IFX (group 2), and in two patients (16.7\%) receiving MSCs (group 1), discomfort in the perianal region, discharge from the fistula and moderate pain has appeared again. Relapse occurred in patients with a partial clinical response to biological therapy. In general, the efficacy of MSCs and anticytokine therapy in patients with CD for six months of

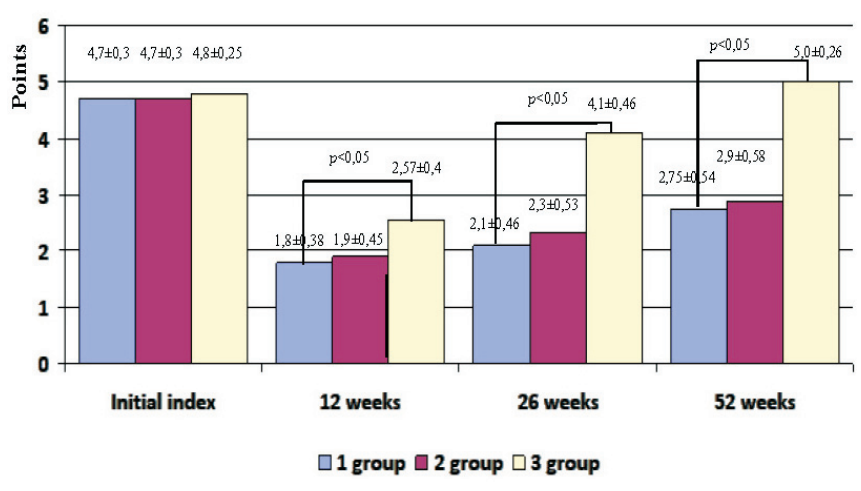

Fig. 5. Dynamics of perianal activity of Crohn's disease in different groups of patients. 
follow-up was comparable (RR 1.11; 95\% CI 0.58-2.12, $p=0.9)$. One patient $(7.1 \%)$ of the $3^{\text {rd }}$ group with a partial clinical response to the therapy experienced a relapse of CD.

Thus, the effectiveness of cell therapy in patients of the $1^{\text {st }}$ group was significantly higher than in patients of the 3rd group who received antibacterial and immunosuppressive therapy (RR 0.93 ; 95\% CI 1.35-64.34, $p=0.0056$ ). After six months, in the $1^{\text {st }}$ group, the average PCDAI was $2.1 \pm$ 0.5 points, in the $2^{\text {nd }}$ group $-2.3 \pm 0.5$ points. In the $3^{\text {rd }}$ group, the average PCDAI was $4.1 \pm 0.5$ points, which was significantly higher than in the $1^{\text {st }}$ and $2^{\text {nd }}$ groups of patients with $\mathrm{CD}(p<0.05)$.

After 52 weeks, remission of the disease persisted in seven $(58.3 \%)$ cases in patients of the 1 st group, and six $(60.0 \%)$ (RR $0.97 ; 95 \%$ CI $0.48-1.95 ; p=0.72$ ) in the $2^{\text {nd }}$ group. In the $3^{\text {rd }}$ group, remission remained in one $(7.1 \%)$ patient of 14 (OR 8.17; 95\% CI 1.16-57.3; $p=0.016$ ). After 12 months, a slight increase in the average values of PCDAI in patients of the $1^{\text {st }}$ and $2^{\text {nd }}$ groups was noted: $2.75 \pm 0.54$ and $2.9 \pm 0.58$ points, respectively $(p>0.05)$. In the $3^{\text {rd }}$ group, PCDAI was $5.0 \pm 0.26$ points and was significantly higher than in patients of the $1^{\text {st }}$ and $2^{\text {nd }}$ groups $(p<0.05)$. Thus, after 12 months, patients receiving MSCs (group 1) and BT (group 2) showed a significant decrease in PCDAI compared with patients receiving antibiotics and IS therapy (group 3).

After 24 months of observation, some patients repeatedly experienced perianal manifestations of $\mathrm{CD}$, such as opening of the fistulous tract, mucus discharge or pus from the anus, and the presence of inflammatory changes in the colon. Complete remission remained in five patients $(41.6 \%)$ of the $1^{\text {st }}$ group, and four $(40.0 \%$ ) (RR $1.04 ; 95 \%$ CI $0.38-2.87 ; p=0.72$ ) of the $2^{\text {nd }}$ group. Relapse occurred in six and five patients, i.e. 50.0\% (OR 1.00; 95\% CI $0.43-2.31 ; p=0.67)$. In the $3^{\text {rd }}$ group of patients, relapse of perianal manifestations of $\mathrm{CD}$ occurred in all patients, manifested by an increase in purulent and serous discharge and the appearance of dense induction in the perianal region (OR 0.5 ; 95\% CI $0.28-0.88$; $p=0.01$ ). A comparative assessment of the therapy effectiveness, characterised by clinical remission, response to treatment of patients, relapse of the disease, between the $1^{\text {st }}, 2^{\text {nd }}$, and $3^{\text {rd }}$ groups is presented in Tables 3 and 4.

Patients with a relapse underwent alternative methods of treatment, including surgical ones. Excision of the fistula was required in four (in three patients with transphincteric fistula and in one with rectovaginal fistula) of nine patients with relapse from the $1^{\text {st }}$ and $2^{\text {nd }}$ groups, and obliteration of the extrasphincteric fistula in one of the nine patients. One patient of the $2^{\text {nd }}$ group experienced a relapse and, considering the exacerbation of the inflammatory process in the rectum, an ileostomy was carried out, with the formation of an ileoileoanastomosis and a single-barrel colostomy. Four patients received another version of anticytokine therapy.
Table 3. Comparative evaluation of the effectiveness of therapy in the $1^{\text {st }}$ and $2^{\text {nd }}$ groups of patients with Crohn's disease

\begin{tabular}{|c|c|c|c|c|c|}
\hline Parameter & $\begin{array}{l}1 \text { group } \\
(\mathrm{n} / \%)\end{array}$ & $\begin{array}{l}2 \text { group } \\
(\mathrm{n} / \%)\end{array}$ & RR & $95 \% \mathrm{CI}$ & $p$ \\
\hline $\begin{array}{l}\text { Clinical remission by } 12 \\
\text { week }\end{array}$ & $8 / 66.6$ & $6 / 60.0$ & 1.11 & $0.58-2.12$ & 0.9 \\
\hline Response on the 12 week & $2 / 16.7$ & $2 / 20.0$ & 0.83 & $0.14-4.90$ & 0.7 \\
\hline No response on the 12 week & $2 / 16.7$ & $2 / 20.0$ & 0.83 & $0.14-4.90$ & 0.7 \\
\hline $\begin{array}{l}\text { Clinical remission by } 26 \\
\text { week }\end{array}$ & $8 / 66.6$ & $6 / 60.0$ & 1.11 & $0.58-2.12$ & 0.9 \\
\hline Response on the 26 week & $0 / 0$ & $1 / 10.0$ & - & - & 0.92 \\
\hline $\begin{array}{l}\text { No response / relapse at } 26 \\
\text { week }\end{array}$ & $4 / 33.4$ & $3 / 30.0$ & 1.11 & $0.32-3.84$ & 0.76 \\
\hline $\begin{array}{l}\text { Clinical remission by } 52 \\
\text { week }\end{array}$ & $7 / 58.3$ & $6 / 60.0$ & 0.97 & $0.48-1.95$ & 0.72 \\
\hline Response on the 52 week & $0 / 0$ & $0 / 0$ & - & - & - \\
\hline $\begin{array}{l}\text { No response / relapse at } 52 \\
\text { week. }\end{array}$ & $5 / 41.6$ & $4 / 40.0$ & 1.04 & $0.38-2.87$ & 0.72 \\
\hline $\begin{array}{l}\text { Clinical remission by } 104 \\
\text { week }\end{array}$ & $5 / 41.6$ & $4 / 40.0$ & 1.04 & $0.38-2.87$ & 0.72 \\
\hline Response on the 104 week & $1 / 8.3$ & $1 / 10.0$ & 0.83 & $0.06-11.70$ & 0.54 \\
\hline No response / relapse at 104 & $6 / 50.0$ & $5 / 50.0$ & 1.00 & $0.43-2.31$ & 0.67 \\
\hline
\end{tabular}
week.

Table 4. Comparative evaluation of effectiveness in the 1st and 3rd groups of patients with $\mathrm{CD}$

\begin{tabular}{|c|c|c|c|c|c|}
\hline Parameter & $\begin{array}{c}\text { 1st group } \\
(\mathrm{n} / \%)\end{array}$ & $\begin{array}{c}3 \text { rd group } \\
(\mathrm{n} / \%)\end{array}$ & RR & $95 \% \mathrm{CI}$ & $\mathrm{p}$ \\
\hline $\begin{array}{l}\text { Clinical remission by } \\
12 \text { week }\end{array}$ & $8 / 66.6$ & $1 / 7.1$ & 0.93 & $1.35-64.34$ & 0.0056 \\
\hline $\begin{array}{l}\text { Response on the } 12 \\
\text { week }\end{array}$ & $2 / 16.7$ & $4 / 28.6$ & 0.58 & $0.13-2.65$ & 0.8 \\
\hline $\begin{array}{l}\text { No response / relapse at } \\
12 \text { week. }\end{array}$ & $2 / 16.7$ & $9 / 64.3$ & 0.26 & $0.07-0.97$ & 0.04 \\
\hline $\begin{array}{l}\text { Clinical remission by } \\
26 \text { week }\end{array}$ & $8 / 66.6$ & $1 / 7.1$ & 0.93 & $1.35-64.34$ & 0.0056 \\
\hline $\begin{array}{l}\text { Response on the } 26 \\
\text { week }\end{array}$ & $0 / 0$ & $3 / 21.4$ & - & - & 0.27 \\
\hline $\begin{array}{l}\text { No response / relapse at } \\
26 \text { week. }\end{array}$ & $4 / 33.4$ & $10 / 71.4$ & 0.47 & $0.2-1.11$ & 0.12 \\
\hline $\begin{array}{l}\text { Clinical remission by } \\
52 \text { week }\end{array}$ & $7 / 58.3$ & $1 / 7.14$ & 8.17 & $1.16-57.3$ & 0.016 \\
\hline $\begin{array}{l}\text { Response on the } 52 \\
\text { week }\end{array}$ & $0 / 0.0$ & $1 / 7.14$ & - & - & 0.93 \\
\hline $\begin{array}{l}\text { No response / relapse at } \\
52 \text { week. }\end{array}$ & $5 / 41.6$ & $12 / 85.7$ & 0.49 & $0.24-0.98$ & 0.05 \\
\hline $\begin{array}{l}\text { Clinical remission by } \\
104 \text { week }\end{array}$ & $5 / 41.6$ & $0 / 0.0$ & - & - & 0.028 \\
\hline $\begin{array}{l}\text { Response on the } 104 \\
\text { week }\end{array}$ & $1 / 8.3$ & $0 / 0.0$ & - & - & 0.93 \\
\hline $\begin{array}{l}\text { No response / relapse at } \\
104 \text { week. }\end{array}$ & $6 / 50.0$ & $14 / 100.0$ & 0.5 & $0.28-0.88$ & 0.01 \\
\hline
\end{tabular}

In one patient of the $3^{\text {rd }}$ group with a combination of ulcer/fissures of the anal canal and fistulas of the rectum and progression of the inflammatory process, after six months a coloproctectomy was required. In one patient, perineal surgery by endoscopic balloon dilation and ulcer/fissure excision of the anal canal was performed without a positive result and, due to progression of inflammation in the colon, a 
Table 5. Frequency of transfer of patients to alternative treatment methods due to therapy inefficiency

\begin{tabular}{l|c|c|c}
\hline \multirow{1}{*}{ Parameter } & \multicolumn{3}{c}{ Groups of patients } \\
\cline { 2 - 4 } & $\begin{array}{c}\text { Group 1 } \\
(\mathrm{n} / \%)\end{array}$ & $\begin{array}{c}\text { Group 2 } \\
(\mathrm{n} / \%)\end{array}$ & $\begin{array}{c}\text { Group } \\
3(\mathrm{n} / \%)\end{array}$ \\
\hline $\begin{array}{l}\text { Switch to another anti-TNF- } \alpha \text { drug / } \\
\text { administration of MSCs }\end{array}$ & $3 / 25.0$ & $0 / 0$ & $6 / 42.8$ \\
$\begin{array}{l}\text { Switch to a drug with a different } \\
\text { mechanism of action }\end{array}$ & $0 / 0$ & $1 / 10.0$ & $0 / 0$ \\
$\begin{array}{l}\text { Surgical treatment of perianal lesions } \\
\text { Surgical treatment with closure of }\end{array}$ & $2 / 16.6$ & $2 / 20.0$ & $4 / 28.6$ \\
\end{tabular}

the colon passage and / or placement

of an ileostomy

coloproctectomy was proposed to the patient, from which he refrained. Four of 12 patients ( $3^{\text {rd }}$ group) who had a relapse required the excision of fistulas and the establishment of setons. Six patients of the $3^{\text {rd }}$ group were transferred to biological anticytokine and/or cell therapy (Table 5).

\section{DISCUSSION}

Mesenchymal stromal cells are multipotent cells that present in all tissues of the body and are able to differentiate into several types of cells. Friedenstein et al. (1974) first described the concept of MSCs, which they first isolated from the bone marrow. Cells can also be successfully obtained for clinical use from umbilical cord blood or adipose tissue (Zuk et al., 2002; Sensebe et al., 2010). In addition to the ability to differentiate, MSCs are able to suppress the immune reactivity of the mucous membrane and stimulate tissue healing, which is relevant for clinical practice (Bartholomew et al., 2002; Krampera et al., 2003; Stappenbeck and Miyoshi, 2009). Additional studies show that MSCs inhibit T-cell proliferation in vitro (Le Blanc et al., 2003; Augello et al., 2005) and activate programmed cell death (Di Nicola et al., 2002). The specific mechanisms of MSC immunomodulation are not yet clear, but it is known that the effect on target cells occurs in close proximity to the cell and depends not only on intercellular contacts (Di Nicola et al., 2002; Ankrum et al., 2014). Encouraging results demonstrate the potential functional ability of MSCs to influence the immune response and reduce inflammation, confirming their clinical significance for therapeutic transplantation in autoimmune diseases.

Today, MSCs are used to treat refractory forms of CD by systemic transplantation (intravenous administration) with the active luminal form of the disease or by local administration in the perianal form (Knyazev et al., 2014). Therapy of the fistulous form of CD has now shifted from exclusively surgical methods to the use of MSCs and anticytokine therapy. Unfortunately, despite all the achievements, the prolonged closure of the fistula remains at a relatively low level (37\%) (Schwartz et al., 2002).

There are a number of different ways and mechanisms through which MSCs act on tissues damaged by inflammation in the intestine. Their discovery will allow to improve current treatment strategies for $\mathrm{CD}$, and to obtain an extended time of remission. The search for other sources of stem cells in preclinical studies in animals is also important. In addition to understanding fundamental knowledge, protocols for the MSCs usage in the treatment of patients with refractory $\mathrm{CD}$ and other autoimmune diseases should be improved.

\section{CONCLUSION}

Perianal fistulas in CD are characterised by a persistent recurrent course, often deep, with extrasphincter location and accompanied by extensive scarring. Even in the era of the use of anti-TNF- $\alpha$ drugs, they may require the application of a permanent stoma or rectal resection. The results of our study showed that the combination of MSCs and anticytokine therapy for $\mathrm{CD}$ complicated by perianal lesions significantly contributed to faster closure of simple fistulas as well as prolongation of the subsequent remission. In conclusion, we emphasise that the best treatment result is achieved with the concurrent observation of patients by a gastroenterologist and a colorectal surgeon.

\section{REFERENCES}

Aguilera-Castro, L., Ferre-Aracil, C., Garcia-Garcia-de-Paredes, A., Rodriguez-de-Santiago, E., Lopez-Sanroman, A. (2017). Management of complex perianal Crohn's disease. Ann. Gastroenterol., 230 (1), 33-44.

Ankrum, J., Ong, J., Karp, J. (2014). Mesenchymal stem cells: Immune evasive, not immune privileged. Nat. Biotech., 32, 252-260.

Augello, A., Tasso, R., Negrini, S., Amateis, A., Indiveri, F., Cancedda, R., Pennesi, G. (2005). Bone marrow mesenchymal progenitor cells inhibit lymphocyte proliferation by activation of the programmed death 1 pathway. Eur. J. Immunol., 35, 1482-1490.

Bartholomew, A., Sturgeon, C., Siatskas, M., Ferrer, K., Mcintosh, K., Patil, S., Hardy, W., Devine, S., Ucker, D., Deans, R., Moseley, A., Hoffman, R. (2002) Mesenchymal stem cells suppress lymphocyte proliferation in vitro and prolong skin graft survival in vivo. Exp. Hematol., 30, 42-48.

Ciccocioppo, R., Bernardo, M. E., Sgarella, A., Maccario, R., Avanzini, M. A., Ubezio, C., Minelli, A., Alvisi, C., Vanoli, A., Calliada, F., Dionigi, P., Perotti, C., Locatelli, F., Corazzaa, G. R. (2011). Autologous bone marrow-derived mesenchymal stromal cells in the treatment of fistulising Crohn's disease. Gut, 60 (6), 788-798.

Cosnes, J., Cattan, S., Blain, A., Beaugerie, L., Carbonell, F., Parc, R., Gendre, J. P. (2002). Long-term evolution of disease behavior of Crohn's disease. Inflamm. Bowel Dis., 8, 244-250.

Dignass, A., Van Assche, G., Lindsay, J. O., Lemann, M., Soderholm, J., Colombel, J. F., Danese, S., D'Hoore, A., Gassull, M., Gomollon, F. et al. (2010). The second European evidence-based consensus on the diagnosis and management of Crohn's disease: Current management. J. Crohn's Colitis, 4, 28-62.

Di Nicola, M., Carlo-Stella, C., Magni, M., Milanesi, M., Longoni, P., Matteucci, P., Grisanti, S., Gianni, A. M. (2002). Human bone marrow stromal cells suppress T-lymphocyte proliferation induced by cellular or nonspecific mitogenic stimuli. Blood, 99, 3838-3843.

Duijvestein, M., Wildenberg, M. E., Welling, M. M., Hennink, S., Molendijk, I., van Zuylen, V. L., Bosse, T., Vos, A. C. W., de Jonge-Muller, E. S. M., Roelofs, H. et al. (2011). Pretreatment with interferon- $\gamma$ enhances the therapeutic activity of mesenchymal stromal cells in animal models of colitis. Stem Cells., 29,1549-1558.

De la Portilla, F., García-Cabrera, A. M., Rodríguez- Jiménez, R. M., Reyes, M. L., García-Olmo, D. (2016). Autologous and Allogeneic Stem Cell 
Transplantation for Treatment of Crohn's Fistulae/New Insights into Inflammatory Bowel Disease. 262 pp.

https://www.intechopen.com/books/new-insights-into-inflammatorybowel-disease/autologous-and-allogeneic-stem-cell-transplantationfor-treatment-of-crohn-s-fistulae (accessed 26 March 2020).

Friedenstein, A., Chailakhyan, R., Latsinik, N., Panasyuk, A., Keiliss-Borok, I. (1974). Stromal cells responsible for transferring the microenvironment of the hemopoietic tissues. Cloning in vitro and retransplantation in vivo. Transplantation, 17, 331-340.

García-Olmo, D., García-Arranz, M., Herreros, D., Pascual, I., Peiro, C., Rodríguez-Montes, J. A. (2005). A phase I clinical trial of the treatment of Crohn's fistula by adipose mesenchymal stem cell transplantation. Dis. Colon Rectum, 48 (7), 1416-1423.

Garcia-Olmo, D., Herreros, D., Pascual, I., Pascual, J. A., Del-Valle, E., Zorilla, J., De La-Quintana, P., Garcia-Arranz, M., Pascual, M. (2009). Expanded adipose-derived stem cells for the treatment of complex perianal fistula: A phase ii clinical trial. Dis. Colon Rectum, 52 (1),79-86.

Gonzalez-Rey, E., Anderson, P., Gonzilez, M. A., Rico, L., Büscher, D., Delgado, M. (2009). Human adult stem cells derived from adipose tissue protect against experimental colitis and sepsis. Gut, 58 (7), 929-939.

Hellers, G., Bergstrand, O., Ewerth, S., Holmstrom, B. (1980). Occurrence and outcome after primary treatment of anal fistulae in Crohn's disease. Gut, 21 (6), 525-527.

Khalif, I. (2013). Clinical Guidelines for the Diagnosis and Treatment of Adult Patients with Chronic Paraproctitis (fistulas of the anus, fistula of the rectum). Association of Coloproctology Russia, Moscow. 20 pp.

Knyazev, O. V., Parfenov, A. I., Shcherbakov, P. L., Ruchkina, I. N., Konoplyannikov, A. G. (2013). Cell therapy for refractory Crohn's disease. Cell Technol. Biol. Med., 3, 145-152.

Knyazev, O. V., Parfenov, A. I., Shcherbakov, P. L., Konoplyannikov, A. G., Ruchkina, I. N., Lishchinskaya, A. A. (2014). Combined biological therapy of the fistula form of Crohn's disease. Clinical demonstration. Ther. Arch., 86 (2), 102-105.

Krampera, M., Glennie, S., Dyson, J., Scott, D., Laylor, R., Simpson, E., Dazzi, F. (2003). Bone marrow mesenchymal stem cells inhibit the response of naïve and memory antigen-specific $\mathrm{T}$ cells to their cognate peptide. Blood, 101, 3722-3729.

Le Blanc, K., Tammik, C., Rosendahl, K., Zetterberg, E., Ringden, O. (2003). HLA expression and immunologic properties of differentiated and undifferentiated mesenchymal stem cells. Exp. Hematol., 31, 890-896.

Lei Yea, Xiaowei Wua, Na Yua, Jingxin Panb, Lianming Liaoc, Fangyu (2016). Clinical efficacy and safety of stem cells in refractory Crohn's disease: A systematic review. Wang J. Cell. Immunother., 2 (1), 21-27.

Lichtenstein, G. R., Van, S., Bala, M., Blank, M., Sands, B. E. (2005). Infliximab maintenance treatment reduces hospitalizations, surgeries, and procedures in fistulizing Crohn's disease. Gastroenterology, 128, 862-869.

Munkholm, P., Langholz, E., Davidsen, M., Binder, V. (1995). Disease activity courses in a regional cohort of Crohn's. Scand. J. Gastroenterol., 30, 699-706.
Panes, J. (2016). Stem cell therapy for perianal fistulas in Crohn's disease. Gastroenterol. Hepatol., 12 (10), 637-640.

Rutgeerts, P., Feagan, B. C., Lichtenstein, G. R., Mayer, LK. F., Schreiber, S., Colombel, J. F., Rachmilewitz, D., Wolf, D. C., Olson, A., Bao, W., Hanauer, S. B. (2004). Comparison of scheduled and episodic treatment strategies of infliximab in Crohn's disease. Gastroenterology, 126, $402-413$.

Sachar, D. B., Andrew, H. A., Farmer, R. G., Pallone, F. (1992). Proposed classification of patient subgroups in Crohn's disease. Gastroenterol. Intern., 5, 141-154.

Sandborn, W. J., Fazio, V. W., Feagan, B. C., Hanauer, S. B. (2003). AGA technical review on perianal Crohn's disease. Gastroenterology, 125, 1508-1530.

Schnitzler, E., Fielder, H., Ferrante, M., Noman, M., Arijs, I., Assche, G. V., Hoffman, I., Van Steen, K., Vermeire, S., Rutgeerts, P. (2009). Mucosal healing predicts long-term outcome for maintenance therapy with infliximab in Crohn's disease. Inflamm. Bowel Dis., 15, 1295-1301.

Schwartz, D. A., Loftus, E. V., Jr., Tremaine, W. J., Panaccione, R., Harmsen, W. S., Zinsmeister, A. R., Sandborn, W. J. (2002). The natural history of fistulizing Crohn's disease in Olmsted County, Minnesota. Gastroenterology, 122 (4), 875-880.

Sensebe, L., Krampera, M., Schrezenmeier, H., Bourin, P., Giordano, R. (2010). Mesenchymal stem cells for clinical application. Vox Sang, 98, 93-107.

Solberg, I. C., Yarn, M. H., Hoie, O., Stray, N., Sauar, J., Jahsen, J., Moum, B., Lygren, I. (2007). Clinical course in Crohn's disease: Results of a Norwegian population-based ten-year follow-up study. Clin. Gastroenterol. Hepatol., 5, 1430-1438.

Solberg, I. C., Lygren, I., Jahnsen, J., Vatn, M. H. (2008). Mucosal healing after initial treatment may be a prognostic marker for long-term outcome in inflammatory bowel disease. Gut, 57, A15.

Stappenbeck, T., Miyoshi, H. (2009). The role of stromal stem cells in tissue regeneration and wound repair. Science, 324, 1666-1669.

Tang, L. Y., Rawsthorne, P., Bernstein, C. N. (2006). Are perineal and luminal fistulas associated in Crohn's disease? A population-based study. Clin. Gastroenterol. Hepatol., 4 (9), 1130-1134.

Tsyb, A. F., Konoplyannikov, A. G., Kolesnikov, A. I., Pavlov, V. V. (2004). The preparation and use in medicine, cell cultures of mesenchymal stem cells of bone marrow. Bull. Russ. Acad. Med. Sci., 59 (9), 71-76.

Williamson, P. R., Hollinger, M. D., Larch, S. W., Ferrara, A. (1995). Twenty-year review of the surgical management of perianal Crohn's disease. Dis. Colon. Rectum, 38, 389-392.

Zuk, P., Zhu, M., Ashjian, P., De Ugarte, D., Huang, J., Mizuno, H., Alfonso, Z. C., Fraser, J. K., Benhaim, P., Hedrick, M. H. (2002). Human adipose tissue is a source of multipotent stem cells. Mol. Biol. Cell, 13, 4279-4295.

Received 5 February 2020

Accepted in the final form 17 March 2020

\section{CILMES ŠŨNU TERAPIJA PACIENTIEM AR PERIANĀLO KRONA SLIMĪBU}

Pētījuma mērḳis bija salīdzināt kombinētās terapijas (lokālās un sistēmiskās lietošanas) efektivitāti ar kaulu smadzeņu mezenhimālo stromu šūnām (MSS), anticitokīnu terapiju ar infliksimabu (IFX) un antibiotiku (AB) / imūnsupresīvo (IS) terapiju attiecībā uz vienkāršu perianālo Krona slimības (KS) fistulas slēgšanu. Mūsu pētījumā 1. pacientu grupa, vecumā 19-58 gadi (vid. 29) (n = 12), saṇēma MSS kultūru atbilstoši shēmai gan sistēmiski, gan lokāli. 2. pacientu grupa, vecumā 20-68 gadi (vid. 36) (n = 10) saņēma anticitokīnu terapiju ar infliksimābu (IFX) atbilstoši shēmai. 3. grupa, vecumā 20-62 (vid. 28) (n =14), san̄ēma antibiotikas (ẢB) un imūnsupresorus (IS). Efektivitāti novērtēja ar Krona slimības perianālās aktivitātes indeksu (PCDAI) un recidīvu biežumu. Pēc 12 nedēḷām vienkāršo fistulu slēgšanu 1. grupas pacientiem novēroja 8 no 12 (66,6\%) pacientiem, 2. grupā -6 no 10 (60,0\%), 3. grupā 1 no 14 (7,1\%) pacientiem. Pēc sešiem mēnešiem vienkāršās fistulas slēgšana tika saglabāta pirmās grupas pacientiem 8 no $12(66,6 \%)$ pacientiem, 2 . grupā — 6 no 10 $(60,0 \%)$, 3. grupā 1 no 14 (7,1\%) pacientiem. KS pacientiem ar perianālajiem bojājumiem kombinētā šūnu un anticitokīnu terapija ievērojami veicina biežāku un ilgstošāku vienkāršo fistulu slēgšanu, kā arī slimības atkārtošanās biežuma samazināšanos, salīdzinot ar antibiotiku/imūnsupresoru terapiju. 